\title{
Obstacles and Performance of Agribusiness Enterprises: Evidence from South-Kivu Eastern Democratic Republic of Congo
}

\author{
Jacques Sadiki $^{1,2}$, Stany Vwima ${ }^{2}, \&$ Philippe Lebailly ${ }^{1}$ \\ ${ }^{1}$ Economic and Rural Development Unit, Faculty of Gembloux Agro-Biotech, Liege University, Belgium \\ ${ }^{2}$ Faculty of Agricultural and Environmental Sciences, Université Evangélique en Afrique Bukavu, Democratic \\ Republic of Congo \\ Correspondence: Jacques Sadiki. E-mail: jacksadiki@live.com/Jsadiki@doct.uliege.be
}

Received: July 21, $2020 \quad$ Accepted: July 27, $2020 \quad$ Online Published: October 31, 2020

doi:10.5539/ass.v16n11p7 URL: https://doi.org/10.5539/ass.v16n11p7

\begin{abstract}
The objective of this study is to analyze differences between business obstacles and performance by their location using 92 food and agribusiness firms operating in rural and urban areas. Descriptive statistics, chi-square and analysis of variance are used to evaluate data collected through household surveys. Chi-square test are used to identify relationships between location and enterprises characteristics and business obstacles. Results reveal a less participation of female in ownership and management. Access to finance still the main obstacle faced by all firms. Scarcity of electricity, transportation cost and lack of equipment are perceived as severe and moderate obstacles. The analysis of variance show that urban firms are able generate higher profit margin than rural firms. These results are helpful for policymakers to promote food and agribusiness sector in order to reduce poverty and enable SME growth in Eastern of the Democratic Republic of Congo (South Kivu region).
\end{abstract}

\section{Introduction}

Congolese agribusiness sector had been neglected for several decades (The Economist Intelligence Unit, 2000) while agriculture and agribusiness together are projected to be in 2030 a 1 trillions \$ industry in Sub-Saharan Africa (The World Bank, 2013). Mostly composed by unregistered micro and small enterprises, South Kivu food and agribusiness sector have been victims of the fallout of armed conflict and looting that led some large companies to reduce their productive capacity and others to cease their activities (Vwima, 2014). In addition, several agricultural policies have been adopted but failed to boost the agricultural sector as they have been geared towards improving the business environment of major mining companies at the expense of agriculture (Lebailly, Michel, \& Ntoto, 2014) and promoting local small business. Programs implemented by the Congolese government with its multiple partners for supporting SMEs and agribusiness to provide primary production and downstream support service failed too (Kabango, 2015). None can deny the major role played by Small and medium-sized food and agribusiness enterprises in development and economic growth in less developed countries cannot be denied (Ayyagari et al., 2007; Berry et al., 2000; De \& Nagaraj, 2014). Development of food industry helps increasing food production, reduces national dependence on imports, save foreign currency, enhance value addition to farm outputs by increasing their importance and place in local consumption (Shalev, Gross-Tsur, Wine, \& Amir, 1988). SME are greater utilizer of local raw materials, generate employment, provide an avenue for self-employment (Okon \& Edet, 2016; Beck, et al., 2005). Through SMEs individuals can be able to use little capital to finance their activities than in larger ones (Fida, 2008).

However, SMEs are confronted with a number of challenges such as, lack of infrastructure, lack of managerial training, unskilled workforce, (Liedholm et al., 1994; Brako Ntiamoah, Li, \& Kwamega, 2016), higher transaction costs (Abedian \& Antonie, 2001; Peel \& Wilson, 1996), shortages of raw materials, international access to international markets (Kimura, 2003) including finance and strong government policies (Lighelm \& Cant, 2003). These challenges hinder SMEs performance and make them inconvenient to be successful.

Various studies on business performance of SME have mainly focused on Size, location, as well as entrepreneur's personal characteristics, including firms internal and external characteristics. Similarly, the current study will attempt compare differences between business location with enterprise characteristics, obstacles and performance in food and agribusiness sector. Within Congolese context, little study has been done 
to explore firm performance issue to small and medium-sized enterprises in informal sector. Findings of this study will enable policy makers to better define supportive policies for this growth-promoting and poverty-reducing sector in both rural and urban settings.

Therefore, the current paper will be testing three conjectures, formulated as follows:

H1: There are no differences in profiles among food and agribusiness enterprises across their location (rural or urban area)

H3: There are no differences in business obstacles among food and agribusiness enterprises across their location.

H2: There are no differences in business performance among food and agribusiness firms.

\section{Conceptual Framework}

\subsection{Performance}

Performance in Small and Medium-Sized Enterprises has been defined in various ways in earlier studies. The context in which research is conducted always stands as one of the key drivers of business performance (Lussier \& Pfeifer, 2001). According to (Giovannetti et al., 2013) business performance as the capacity to generate acceptable outcomes, including actions and the magnitude to a firm's propensity to export; it can also be perceived as the ratio of operating profit (Anderson \& Reeb 2003; Kulchina, 2016). Debate on firm performance has been divided into two main groups; economics (financial) and non-financial (non-pecuniary). Financial measures for "business success or growth include return on assets, sales growth, profits, employee growth, and survival rates while non-pecuniary measures include intangible constructs such as customer satisfaction, personal development, achievement, corporate reputation, happiness, and market share" (Islam et al., 2011; Masuo, Fong, Yanagida, \& Cabal, 2001;Walker \& Brown, 2004). Financial measures are the best indicators of business performance because they can be individually measured and verified ((Dowling \& Helm, 2006; Thrikawala, 2011; Watson, 2007). They also inform about success of a company (Harash et al., 2014). For instance, firms financially performant are able to achieve their objectives and able to survive (Calori et al., 1989).

Borrowing from the afore-mentioned literature, the current paper uses input ratios, output indicator and output ratios as measures of business performance. However, despite the flurry of research on SMEs' performance, there is no consensus on the factors that drive SME's performance. Various researches investigated the performance of SMEs across different settings, from developed to least-developed countries, and utilized different methodologies (Ndiaye et al., 2018). Although robust analyses of SME performance are recommended, it is difficult to obtain appropriate information, such as books of accounts, because information and knowledge management systems are missing in many of them (Byron \& Friedlob, 1984). Ali (2016) studied the performance of small and medium-sized food agribusiness enterprises in India by analyzing the relationship between input ratios such as cost of raw material per total cost, and output ratios (total annual sales per total cost and the capacity of utilization) to define firm performance.

\subsection{Firm Location}

Firm location remains one of the key drivers of business performance. Several studies conducted on the role of location on business performance, whether in developed or less developed countries, had come to numerous conclusions emphasizing in one way or another, or to some extent the importance of this variable in business performance appraisal. While some authors had found no influence of location on business performance, others on the other hand, through their results, had indicated some mixed relationship between the two variables. The remoteness to sources of raw materials or their proximity, as well as a practical road network will influence strategic business location (Ilian \& Yasuo, 2005). Some firms can decide to locate in rural or urban areas while others can decide to remain local or go international in small or large cities (Sridhar \& Wan, 2010). Esteban et al., (2010), stressed that the selection of business location in a geographic area is connected with the categories of product or service the firm tend to supply. For Sobri et al., (2011), being set in an agglomeration endowed with information resources conducts firm to be performant than in a place less endowed with information resources. (Audretsch \& Dohse, 2007) tried to examine the link between the performance of the latest technology companies measured in terms of employment with geographic location and found that firm's growth was not influenced by firm characteristics nor firms geographic location. On the contrary, (Goel \& Nelson, 2018) found that companies set in Island exhibited less performance in terms of innovation than those set in mainland counterpart. Island companies face less pressure to innovate. Freeman et al., (2012), explored how regional location vs metropolitan impact a SME access to firm's resource and capabilities. Their study findings showed 
that that location was directly associated with a firm's performance. In broad, the conclusion of authors' analyses stipulated that location can be seen as an antecedent for firm resources capabilities, that successively explains firm's export performance (Freeman et al., 2012).

Therefore, location moderates the connection between firm characteristics, external issues and firm characteristics. Companies strategically set come through bigger performance than those that do not seem strategically set. This result suggests that policy makers, entrepreneurs and owner-managers ought to assume on the way to utilize location consider the event of business and entrepreneurship development (Sobri et al., 2011). Business location of the business will be considered the geographic location of the business without taking into consideration the previous decisions regarding its choice.

\subsection{Business Obstacles}

According to authors, entrepreneurs in developing countries face quite similar obstacles. Access to electricity, political factors, regulation, managerial skills, location and tax rates (Gree \& Thurnik, 2003; Wang, 2016). One of the most serious obstacles faced by African SME is access to short and long term financial capital hampering their development and growth (Wangmo, 2015; Chu et al., 2007). The bigger is a firm the less access to finance is perceived as a barrier. Lack of collateral requirement to secure loans and high interest rate do not allow SME to fulfil condition of obtaining credit from legal financial institutions (Peel \& Wilson, 1996; Spring \& McDade, 1998; Levy, 1993; Fanta \& Bayene, 2016). The higher the taxes rated by SME the lesser their turnover and probability of their income grow (Ishengoma \& Kappel, 2011). The effect of taxes on SME growth potential can be explained by the preference of SME to remain small avoiding formalization (Tokman, 2001). Several factors affect SME performance and growth. Authors have revealed several factors such as entrepreneur's characteristics, firm's characteristics, internal and external factors.

\section{Data and Methodology}

The structure of Congolese economy is dominated by primary sector performance. Agriculture is playing a really dominant role within the country's economy. The share of agriculture in total GDP is estimated to be about $30-40 \%$. Approximately 65 percent of informal firms are active in the agroindustry and food trade, retail trade, and repair services. The informal sector in the Democratic Republic of Congo is heterogeneous in many ways. Differences are noticeable across the individual characteristics of the owner of informal firms (Adoho \& Doumbia, 2017). The sample of this study comes from a 2018 survey led to investigate firm characteristics, business obstacles and business performance in unregistered firms in eastern of Democratic Republic of Congo in South Kivu region, and operating in food and agribusiness sector. The survey population was identified using two criteria. The study selected firms operating in food and agribusiness in informal sector and also aimed at checked whether the enterprise had a working place different from the owner's house in order to reduce the sample. Bakery, traditional beer processors were excluded in the study. The questionnaire were directly administrated to the owner or the firm managers. The study had a response rate of $79,3 \%$ resulting in a population of 116 firms gathered through processors listing. Finally, 92 food and agribusiness firms were selected. Firms have been categorized according to agricultural product processed such as maize, cassava, fruits, palm oil. Structured questionnaires contained diverse firm's characteristics such as location, number of employees, age and ownership. Performance indicators such as input and output ratios and constraints faced by these firms. Constraints identified included access to finance, electricity, unskilled workforce, access to modern equipment, product quality, access to information, taxes, corruption, raw material supply and competition. For all the above-mentioned constraints, a 5 Likert scale was used as following: $1=$ no obstacle; $2=$ minor obstacle; $3=$ moderate obstacle; $4=$ major obstacle; $5=$ very severe obstacle. To measure business performance, input and output ratios were used (Ali, 2016). Input ratios comprised "wage per employees, cost of raw material by the total cost of production, cost of energy (electricity, fuel, wood or charcoal) by the total of cost of production. Output ratios were generated to understand performance of firms in terms of the total sales by the cost of production, profitability ratio and profit margins. Business obstacles were categorized into internal and external. Primary data collected from field work were analyzed using SPSS 25. Descriptive statistics, tables, chi-square and analysis of variance have been used to understand business performance difference among rural and urban firms and agribusiness in South-Kivu.

\section{Results and Discussion}

\subsection{Firm Characteristics by Location}

Several studies have investigated the relationship between firms location, their characteristics, namely ages, and size. Out of the 92 MSMEs surveyed, 72 (78.3\%) were Micro and 20 (21.7\%) were Small. According to the Congolese legislation, a micro enterprise employs 1 to 5 employees and a small enterprise 6 to 50 people. 
Table 1. Firm's characteristics

\begin{tabular}{|c|c|c|c|c|c|c|c|}
\hline \multirow{2}{*}{ Indicators } & \multicolumn{2}{|c|}{ Urban } & \multicolumn{2}{|c|}{ Rural } & \multirow{2}{*}{ Chi-square } & \multirow{2}{*}{ df } & \multirow{2}{*}{$\mathrm{P}$} \\
\hline & $\mathrm{N}$ & $\%$ & $\mathrm{~N}$ & $\%$ & & & \\
\hline \multicolumn{5}{|c|}{ Types } & .163 & 1 & .686 \\
\hline Private & 38 & 86,4 & 40 & 83,3 & & & \\
\hline Cooperative & 6 & 13,6 & 8 & 16,7 & & & \\
\hline \multicolumn{5}{|c|}{ Management delegation } & .006 & 1 & .939 \\
\hline Yes & 29 & 65,9 & 32 & 66,7 & & & \\
\hline No & 15 & 34,1 & 16 & 33,3 & & & \\
\hline \multicolumn{5}{|c|}{ Size } & $22.791 *$ & 1 & .000 \\
\hline Micro & 25 & 56,8 & 47 & 97,9 & & & \\
\hline Small & 19 & 43,2 & 1 & 2,1 & & & \\
\hline \multicolumn{5}{|c|}{ Experience } & $9.043^{*}$ & 2 & .011 \\
\hline$<10$ years & 24 & 54,5 & 40 & 83,3 & & & \\
\hline $10-19$ years & 14 & 31,8 & 6 & 12,5 & & & \\
\hline$>20$ years & 4 & 13,6 & 2 & 4,2 & & & \\
\hline \multicolumn{5}{|c|}{ Firms with female owner } & 1.963 & 1 & .161 \\
\hline Yes & 36 & 81,8 & 44 & 91,7 & & & \\
\hline No & 8 & 18,2 & 4 & 8,3 & & & \\
\hline \multicolumn{5}{|c|}{ Part-time workforce } & $11.255^{*}$ & 2 & .004 \\
\hline None & 12 & 31,6 & 26 & 68,4 & & & \\
\hline $1-5$ & 19 & 50 & 19 & 50 & & & \\
\hline $6-10$ & 13 & 81,2 & 3 & 18,8 & & & \\
\hline
\end{tabular}

*significance at 0,05 level, $\mathrm{N}=$ Number, $\mathrm{P}=\mathrm{p}$ value

Source: Own data

As shown in Table 1 above, the chi-square test is statistically significant between location and business size $(\chi 2=$ 22.791, $P<0.05$ ), confirming that location could particularly be related to business size. In fact, results showed that most of micro enterprises were located in rural areas. However, no difference was found between location and type of firms. A lower participation of women in daily management and ownership was also observed in both areas. Only $13 \%$ of SME surveyed were managed or owned by a woman. On the contrary, in several studies conducted in Sub-Saharan Africa, Caribbean and Latin America women represented over 75\% of entrepreneurs as compared to men who only 48\% (GEM, 2010). In West Africa, (Gradval, Broutin, \& Delmas, 2008) found that most of micro and small-scale food and agribusiness firms were women-led even though they are not often recognized and their economic role underestimated. Based on a literature review Duflo, (2011) found evidence that the more women are empowered the more economic development is promoted because they are closely correlated. According to the author, "equity between men and women is only likely to be achieved by continuing policy actions that favor women at the expense of men, possibly for a very long time".

Daily labor utilization in processing units depends on daily work load. Nevertheless, since some SMEs do not have enough effector tasks during the week, they prefer using part-time workforce in order to reduce operating costs. Our findings showed that rural firms use 1 to 5 part-time employees whereas in urban area 6 to 10 part-time employees are used, explaining the significant difference found between daily labor utilization and firm location $(\chi 2=21.883, P<0.05)$. Out of 92 firms surveyed, $38(41 \%)$ do not use part-time employees with 26 and 12 firms respectively in rural and urban area. This finding could also be mainly explained by the daily quantity of processed products as well as the financial capacity that the MSMES would hold in urban areas. The distribution of firms by age was also found to be varying with their location $(\chi 2=9.043, P<0.05)$. Urban MSMEs as reported by our findings appear less older than those located in rural areas. MSMEs younger than ten years of experiences represent $69.6 \%$ with 40 firms them located in rural areas. MSME's age can directly be related to the dynamics of activity creation in a specific setting as well as the experience owned by entrepreneurs in a given sector. (FURAHA, 2017) pointed enterprise's age can imply the dynamics of activity creation in a setting and experience owned by entrepreneurs in a certain sector whereas entrepreneurs experience cannot necessarily influence SME performance. The predominance of start-ups in an industry may also raise questions about the longevity of firms in certain industries. 
Unsurprisingly, most of MSMEs surveyed were privately owned, few of them (33.3\%) were led by a non-owner manager. The management delegation of an MSME can inform about the diversity of activities carried out by its owner. Management can be done either by a family member which is more convenient or by one of his friends.

Therefore, the hypothesis $\mathrm{H} 1$ which stipulates that there are no differences in enterprises characteristics by their location is rejected. Size of firms is significantly linked with their location. MSME in urban area were reported employing more part-time workforce than those in the countryside. The age of firm was also found positively correlated with its location. Female participation in management and ownership of food and agribusiness firms on the other side was relatively low in South Kivu. This implies that women are still more constrained in accessing resources than their men counterparts.

\subsection{Business Obstacles by Firm Location}

Various studies have investigated obstacles that affect performance of SME in specific areas (Mather, 2005). Wang, (2016) explored the main challenges faced by SME in developing countries by categorizing them in groups. He realized that access to finance was the most significant obstacle which hindered business performance and growth. Others included inadequately educated workforce, tax administration, Corruption, electricity, political instability, transportation. In the present paper, thirteen parameters were used to measure "internal obstacle" and "external obstacles" faced by firms in Eastern of Democratic Republic of Congo (South-Kivu region).

Table 2. Business obstacles

\begin{tabular}{|c|c|c|c|c|c|}
\hline Business obstacles & \multirow{2}{*}{ Urban } & \multirow{2}{*}{ Rural } & \multirow{2}{*}{$\mathrm{F} 1$} & \multirow{2}{*}{$\mathrm{df}$} & \multirow{2}{*}{ Sig. } \\
\hline Internal & & & & & \\
\hline Access to finance & 4.250 & 4.470 & .353 & 1 & .554 \\
\hline Managerial skills & 1.955 & 2.917 & $16.266^{*}$ & 1 & .000 \\
\hline Raw material supply & 3.455 & 3.104 & 1.721 & 1 & .193 \\
\hline Electricity & 3.432 & 2.771 & $4.670 *$ & 1 & .033 \\
\hline Access to information & 2.182 & 3.021 & $12.375^{*}$ & 1 & .001 \\
\hline Lack of equipment & 2.886 & 3.792 & $9.389 *$ & 1 & .003 \\
\hline \multicolumn{6}{|l|}{ External } \\
\hline Corruption & 3.525 & 3.229 & 1.191 & 1 & .278 \\
\hline Competition & 3.182 & 2.958 & .591 & 1 & .444 \\
\hline Taxes & 3.773 & 3.479 & 1.274 & 1 & .262 \\
\hline Low productivity and output quality & 2.295 & 3.021 & $7.648 *$ & 1 & .007 \\
\hline Market segment & 2.386 & 3.313 & $1.7248 *$ & 1 & .000 \\
\hline Transportation & 3.182 & 3.917 & $5.257 *$ & 1 & .024 \\
\hline
\end{tabular}

*significance at 0,05 level

Results presented in Table 2 above show how differently operational obstacles vary from rural to urban areas. Seven out the thirteen obstacles were found statistically significant. Firms mainly face at moderate and severe level of challenges in business operations.

Access to finance remains the major obstacle faced by SMEs with an average of $(\mu=4,470)$ in rural and $(\mu=$ $4,250)$ in urban area. Olawale et al., (2010) found the same result while analyzing obstacles of growth of new SME in South Africa. Raw material supply in food and agribusiness remains also moderate obstacle $(\mu=3,455$ urban and $\mu=3,104$ rural) in both areas. Meanwhile transportation of raw material was positively and significantly correlated with firm location. The absence of appropriate transportation network hampers distribution of raw materials and the transportation of finished products to the market. This problem is compounded by poor storage or warehousing facilities and access to affordable shipping (Mercer, 2011). Most African agricultural production is still done by smallholders, however, production within this system is largely stagnant and its commercialization linking farm producers to commercial markets is generally complex and difficult (Agra 2009; Kirsten et al., 2009). Other issues revealed are delay in delivery, insufficient providers, higher cost of handling and finance issues. Processing by micro-enterprises is often irregular and seasonal in nature, stopping when raw material supplies are exhausted; they rarely have alternative products for the off-season (Dietz et al., 2000).

Nevertheless, there was a significant relationship between location and certain obstacles. Lack of equipment (F=9.389, $P<0.05)$, access to information $(\mathrm{F}=12.375, P<0.05)$, product quality $(\mathrm{F}=7.648, P<0.05)$, market 
segment $(\mathrm{F}=17.248, P<0.05)$, were found to be statistically significant and were perceived severe in rural area than in urban. This implies that access to information in the rural environment remains weak, the obsolescence of machines and access to spare parts entail momentary stops in rural environment. This also makes the output quality to be perceived as an obstacle by some. (Dietz et al., 2000) emphasized that "In sub-Saharan countries, technical maintenance services in rural areas are poorly developed. Entrepreneurs often have to be their own mechanics. Replacing worn parts can become a nightmare for entrepreneurs. Spare parts are often only available from the organization that has developed the 'appropriate' equipment, resulting in people having to travel long distances to procure the badly needed parts".

Unsurprisingly, results on shortage of electricity showed that this variable was statistically linked to location of businesses $(\mathrm{F}=4.670, P<0.05)$. Untimely cuts in urban area are one of the major constraints that reduce time of activity, and therefore, the daily turnover of SMEs. Power supply time varies between 3 and 5 hours per day. This constraint is considered moderate in the urban environment than in rural areas for two reasons; quantity of raw material to process per day and the number of working days per week. In rural areas, processing activities are more intense during days commonly known as "market days", two to four days a week. The World Bank (2017) revealed that in Democratic Republic of Congo 21.8 days per month companies experience load shedding with a duration of 7.5 hours, which causes a turnover loss from 5.5 to $22.7 \%$. It should be mentioned in passing that all these averages are relatively higher than in other Sub-Saharan Countries. Higher taxation and corruption are still perceived in both urban and rural areas as a scourge to their development. In our area of investigation, dozen taxes has been identified, making corruption more common in order to escape legal taxation. It should be emphasized that entrepreneurs' ignorance of their rights and duties and processors organizations malfunctioning would also be the basis of their subjection to this multitude of government taxes.

From the results above it can be argued that business obstacles differ from rural to urban area. Broadly speaking, firms perceive obstacles at moderate and severe level in both areas. Therefore, the hypothesis which assumes that There are no differences in business obstacles among food and agribusiness enterprises across their location therefore rejected.

\subsection{Business Performance by Firm Location}

To measure business performance, Analysis Of Variance was used. Results show that Input ratios, output and output ratios varied with firm location.

Table 3. Differences in Business performance and by firm's location

\begin{tabular}{|c|c|c|c|c|c|c|c|}
\hline \multirow{2}{*}{ Input Ratios } & \multicolumn{2}{|c|}{ Urban } & \multicolumn{2}{|c|}{ Rural } & \multirow{2}{*}{$\mathrm{F}$} & \multirow{2}{*}{ df } & \multirow{2}{*}{ Sig. } \\
\hline & Mean & Std. Dev & Mean & Std. Dev & & & \\
\hline Wages/number of employee & .17 & .272 & .108 & .099 & 2.594 & 1 & .111 \\
\hline Cost raw material/total cost & .72 & .115 & .768 & .074 & $5.085^{*}$ & 1 & .027 \\
\hline Cost of energy/total cost & .03 & .046 & .046 & .030 & $4.765^{*}$ & 1 & .032 \\
\hline Rent for land/total cost & .034 & .012 & .046 & .016 & $4.574 *$ & 1 & .035 \\
\hline \multicolumn{8}{|c|}{ Output and output ratios } \\
\hline Annual sale/total cost & 14.42 & .21 & 13.78 & .27 & 1.572 & 1 & .213 \\
\hline Profitability ratio & .31 & .09 & .29 & .11 & 0.637 & 1 & .427 \\
\hline Profit margin & 3.4 & 25.55 & 1.20 & 7.60 & $35.124 *$ & 1 & .000 \\
\hline
\end{tabular}

*Significance at 0,05 level

From the Table 3 above, the average wage per employee ratio in urban firms $(\mu=0.17)$ seems to be less higher than that applied in rural enterprises $(\mu=0.10)$. There is a significant difference in acquisition of the raw material by firm location $(\mathrm{F}=5.085, P<0.05)$. In rural companies cost of raw material represent $76.8 \%$ per unit total while in urban it represents $72 \%$, it can be explained by transportation cost and due to road infrastructures. Also, in the previous sections, it has been shown that firms located in rural areas were micro (1-5employees) while those in urban areas were small (6-50 employees). Ali (2016) showed that the costs of raw material in companies were lower in a growing order of company size. A positive relationship $(\mathrm{F}=4.756, P<0.05)$ was found between the ratio of energy cost per total cost with firm location. The shortage of intensity and the restrictive utilization of generators and the quantity of long stretches of power supply in rural areas may clarify the significant expense of energy in these firms. The supply of electricity is one of the major constraints faced by SMEs in the developing country. The DR Congo is one of countries whose population has the least access to electricity with less than one percent in rural areas and 49.19\% in urban areas (World Bank, 2017). On the other hand, the cost of renting workplaces by urban enterprises was higher than those of rural areas $(\mathrm{F}=4.574, P<0.05)$. Most urban businesses 
rent out workplaces and their cost is sometimes much higher in rural areas where sometimes certain processing units are established on the land of their owners. The analysis showed a significant difference between cost of rent per total cost in urban area and the countryside $(\mathrm{F}=4.574, P<0.05)$.

Business performance is measured by a number of indicators, including the profitability ratio, the share of revenue in total cost of production, and profit margins (Chirwa, 2008). Breaks down of the table above show that urban ventures create higher turnover than those located in rural areas. It is the equivalent for the profitability ratio which is somewhat higher. Moreover, results show a significant difference $(\mathrm{F}=1.572, P<0.05)$ between the profit margin that emerges from urban and rural businesses.

\section{Conclusions}

This paper compares differences in enterprise's characteristics, business obstacles and performance by firm location. It provides insights into different result found among SME in agribusiness sector in South Kivu.

Firstly the hypothesis stipulating no difference among firm's characteristics was rejected. It has been found that most of firms are sole proprietary with micro-sized enterprises located in rural area and whereas small ones were located in urban area. Female participation in firm management and ownership still very lower in both areas. Part-time workforce utilization was positively correlated to firm location. In countryside firms have less than ten years of experience compared to urban firms aged from 10 up 20 years.

Secondly, our results reveal also that business obstacles perceived in SME vary from the countryside to the urban in South Kivu. Therefore, the second hypothesis was also rejected. Access to finance remains the main obstacle faced by all SME whereas access to information, lack of equipment, scarcity of power, lack of equipment, access to information, low productivity and output quality were statistically significant and perceived as major in countryside firms and moderates in urban firms. Raw material supply, dealing with corruption in daily activities hamper SME performance in both areas.

Thirdly, SME performance was analyzed by different ratios and indicators. No difference was found among SME accordingly to wages paid by employee and the share of annual sale in production cost. Although differences were not significant for these ratios within both areas but urban firms generate higher turnover and their profit margins were significantly higher than those of rural firms. This can imply that the third hypothesis stipulating no difference among business performance in SME was also rejected.

Finally, these results can, as far as possible, be a source for policy makers, entrepreneurs and researchers intending to establish a food and agribusiness sector development model. Certainly, the ratios used may have certain limits to properly determine and explain the performance of companies. The nature of the companies and the non-maintenance of the accounts in the companies surveyed would be the reason these ratios and output indicator choice. Future research may focus on giving more attention on non-financial indicators of performance of these firms.

\section{Acknowledgements}

Authors acknowledge the Université Evangélique en Afrique for manifold support to this work which was graciously been funded through the University project on improvement of research and teaching quality funded by Pain pour le Monde (Projet A-COD-2018-0383).

\section{References}

Abedian, L., \& Antonie, F. (2001). Contemporary challenges facing South African business in a globalizing economy. Development Policy in Africa: Public and Private Perspectives, 29-31. BDC Musanze (2011). Report of Small and Medium Enterprises in Musanze, District; Rwanda, 3-18. Retrieved from http://www.musanze.gov.rw

Abereijo, I. O., lori, M. O., Taiwo, K. A., \& Adegbite, S. A (2007). Assement of the capabilities for innovation by small and medium Industry in Nigeria. African Journal of Business Management, 1(8), 209-217. https://doi.org/10.1016/0887-8994(88)90050-1

Adoho, F. M., \& Doumbia, D. (2017). Informal Sector Heterogeneity and Income Inequality Evidence from the Democratic Republic of Congo. Retrieved from http://www.ecineq.org

Ali, J. (2016). Performance of small and medium-sized food and agribusiness enterprises: Evidence from Indian firms. International Food and Agribusiness Management Review, 19(4), 53-64. https://doi.org/10.22434/IFAMR2016.0024

Anderson, R. C., \& Reeb, D. M. (2003). Founding-family ownership and firm performance: Evidence from the 
S\&P 500. The Journal of Finance, 58(3), 1301-1328.

Audretsch, D. B., \& Dohse, D. (2007). Location: A neglected determinant of firm growth. Review of World Economics, 143(1), 79-107. https://doi.org/10.1007/s10290-007-0099-7

Ayyagari, M., Beck, T., \& Demirguc-Kunt, A. (2007). Small and medium enterprises across the globe. Small Business Economics, 29(4), 415-434. https://doi.org/10.1007/s11187-006-9002-5

Beck, T., Demirguc-Kunt, A., \& Levine, R. (2005). SMEs, growth, and poverty: Cross-country evidence. Journal of Economic Growth, 10(3), 199-229. https://doi.org/10.1007/s10887-005-3533-5

Berry, A. (1984). Land reform and the adequacy of world food production. In J. Montgomery (Ed.), International Dimensions of Land Reform. Westview Press, Boulder.

Brako Ntiamoah, E., Li, D., \& Kwamega, M. (2016). Impact of Government and Other Institutions' Support on Performance of Small and Medium Enterprises in the Agribusiness Sector in Ghana. American Journal of Industrial and Business Management, 6(5), 558-567. https://doi.org/10.4236/ajibm.2016.65052

Byron, E. L., \& Friedlob, G. T. (1984). Small business, Why small businesses fail: Testimony proposes solutions. Management Accounting, 65(7), 16-17.

Calori, R., Livian, Y. F., \& Sarnin, P. (1989). Pour une théorie des relations entre culture d'entreprise et performance économique. Revue française de gestion, 74, 39-50.

Chirwa, E. W. (2008). Effects of gender on the performance of micro and small enterprises in Malawi. Development Southern Africa, 25(3), 347-362. https://doi.org/10.1080/03768350802212139

Chu, H. M., Benzing, C., \& Mcgee, C. (2007). Ghanaian and Kenyan Entrepreneurs: A Comparative Analysis of Their Motivations, Success Characteristics and Problems. Journal of Developmental Entrepreneurship, 12(3), 295-322. https://doi.org/10.1142/S1084946707000691

De, P. K., \& Nagaraj, P. (2014). Productivity and firm size in India. Small Business Economics, 42(4), 891-907. https://doi.org/10.1007/s11187-013-9504-x

Dietz, M. H., Matee, S., \& Ssali, W. (2000). Assessment of the Small-scale Food Processing Subsector in Tanznania and Uganda, Technical Centre for Agricultural and Rural cooperation (ACP-EU). Retrieved from https://cgspace.cgiar.org/bitstream/handle/10568/63584/assessment.pdf?sequence=1

Dorward, A. R., Kirsten, J. F., Omamo, S. W., Poulton, C., \& Vink, N. (2009). Institutions and the agricultural development challenge in Africa. Institutional economics perspectives on African agricultural development, $1,3-34$.

Dowling, M., \& Helm, R. (2006). Product development success through cooperation: A study of entrepreneurial firm. Technovation, 26(4), 483-488. https://doi.org/10.1016/j.technovation.2005.06.015

Duflo, E., (2011). Women's Empowerment and Economic Development. Journal of Economic Literature 2012, 50(4), 1051-1079. https://doi.org/10.1257/jel.50.4.1051

Fanta, A. B. (2016). Complementarity between relationship lending and collateral in SME access to bank credit: Evidence from Ethiopia. Journal of African Business, 17(3), 308-318. https://doi.org/10.1080/15228916.2016.1177785

Freeman, J., Styles, C., \& Lawley, M. (2012). Does firm location make a difference to the export performance of SMEs? International Marketing Review, 29(1), 88-113. https://doi.org/10.1108/02651331211201552

Furaha, M. G. (2017). Analyse comparée des chaines de valeur du riz dans la plaine de la Ruzizi de la Communauté Economique des pays des Grands Lacs (CEPGL) (Doctoral Disseratation). Université de Liège. Retrieved from http://orbi.ulg.ac.be/bitstream/2268/215183/1/THESE Germaine oct2017.pdf

Gerstenmier, A., \& Choho, T. (2015). Fourniture d'intrants agricoles. Retrieved from http://www.afdb.org/ fileadmin/uploads/afdb/Documents/Events/DakAgri2015/Fournitured'intrantsagricoles.pdf

Giovannetti, G., Ricchiuti, G., \& Velucchi, M. (2013). Location, internationalization and performance of firms in

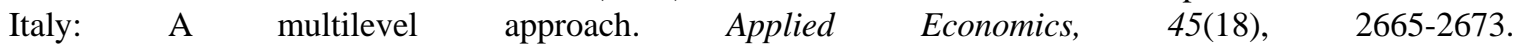
https://doi.org/10.1080/00036846.2012.665597

Global Entrepreneurship Monitor. (2011). The Women's Report 2010. Retrieved from http://www.gemconsortium.org

Goel, R. K., \& Nelson, M. A. (2018). Determinants of process innovation introductions: Evidence from 115 
developing countries. Managerial and Decision Economics, 39(5), 515-525. https://doi.org/10.1002/mde.2922

Gradval, F., Broutin, C., \& Delmas, P. (2008). Le potentiel de développement des micro et petites entreprises agro-alimentaires. In Éd. Gret (Ed.), Trade as a development tool: Partnerships and policies: 1st Conference of the Geneva Trade and Development Forum (p. 11). Crans Montana, Switzerland.

Gree, A., \& Thurnik, C. (2003). Firm selection and industry evolution: The post country performance of new firm. Journal of Evolutionary Economics, 4(4), 243e264.

Harash, E., Fatima, J. A., \& Essia, R. A. (2013). Moderating effect of market practices on the government policy-Performance relationship in Iraq SMEs. Proceedings from 4th Global Conference for Academic Research on Economics, Business and Management (GCAR-EBM). Kuala Lumpur, Malaysia.

Ilian, P. S., \& Yasuo, H. (2005). Influence of location factors on establishment and ownership of foreign investments: The case of the Japanese manufacturing firms in Europe. International Business Review, 14, 577-598.

Ishengoma, E., \& Kappel, R. (2011). Business environment and growth potential of micro and small manufacturing enterprises in Uganda. African Development Review, 23(3), $352-365$. https://doi.org/10.1111/j.1467- 8268.2011.00291

Islam, Aminul, M., Khan, M. A., Zafar, A., Obaidullah, M., \& Alam, M. S. (2011). Effect of Entrepreneur and Firm Characteristics on the Business Success of Small and Medium Enterprises (SMEs) in Bangladesh. International Journal of Business and Management, 6(3), 289-299.

Kabango, M. C. (2015). Characteristics and Critical success factor's Prioritization of MSMEs in Agribusiness: A case of DR. Congo. The International Journal of Management Science and Business Administration, 1(6), 31-41. https://doi.org/10.18775/ijmsba.1849-5664- 5419.2014.16.1008

Kirsten, J., Dorward, A., Poulton, C., \& Vink, N. (2009). Institutional Economic Perspectives on African Agricultural Development. IFPRI, Washington, D.C

Kulchina, E. (2016). Personal preferences, entrepreneurs' location choices, and firm performance. Management Science, 62(6), 1814-1829. https://doi.org/10.1287/mnsc.2015.2199

Lafuenta, E., Vaillant, Y., \& Serarols, C. (2010). Location decisions of knowledge-based entrepreneurs: Why some Catalan KISAs choose to be rural? Technovation, 30(11-12), 590-600. https://doi.org/10.1016/j.technovation.2010.07.004

Lebailly, P., Michel, B., \& Ntoto, R. (2014). Quel Développement pour la RDC? In Conjonctures Congolaises (pp. 45-63). https://doi.org/10.1109/CogInfoCom.2014.7020455

Levy, B. (1993). Obstacles to developing indigenous small and medium enterprises: An empirical assessment. The World Bank Economic Review, 7(1), 65-83. https://doi.org/10.1093/wber/7.1.65

Liedholm, C., Mcpherson, M., \& Chuta, E. (1994). Small enterprise employment growth in rural Africa. American Journal of Agricultural Economics, 76(5), 1177-1182.

Lussier, R., \& Pfeifer, S. (2001). A cross-national prediction model for business success. Journal of Small Business Management, 39(3), 228-237.

Masuo, D., Fong, G., Yanagida, J., \& Cabal, C. (2001). Factors associated with business and family success: a comparison of single manager and dual manager family business households. Journal of Family and Economic Issues, 22(1), 55-73. https://doi.org/10.1023/A:1009492604067

Mather, C. (2005). The growth challenges of small and medium enterprises (SMEs) in South Africa's food processing complex. Development Southern Africa, 22(5), $607-622$. https://doi.org/10.18/037683500364208

Mercer, D. G. (2011). Challenges facing development within the agri-food sector of Sub- Saharan Africa. In 11th International Congress on Engineering and Food (ICEF11) Challenges (pp. 1861-1866). Elsevier Srl, https://doi.org/10.1016/j.profoo.2011.09.273

Murphy, G. B., Trailer, J. W., \& Hill, R. C. (1996). Measuring Research Performance in Entrepreneurship. Journal of Business Research, 36, 15-23. https://doi.org/10.1016/0148-2963(95)00159-X

Ndiaye, N. et al. (2018). Demystifying small and medium enterprises' (SMEs) performance in emerging and developing economies. Borsa Istanbul Review, 18(4), 269-281. https://doi.org/10.1016/j.bir.2018.04.003 
Okon, N. B., \& Edet, T. E. (2016). Small and Medium Scale Business Enterprises as a Veritable Tool for Rural Development in Nigeria: Challenges and Prospects. Journal of Educational Policy and Entrepreneurial Research, 3(3), 87-97.

Peel, M. J., \& Wilson, N. (1996). Working capital and financial management practices in the small firm sector. International Small Business Journal, 14(2), 52-68. https://doi.org/10.1177/0266242696142004

Sobri Minai, M., \& Lucky, E. O.-I. (2011). The Moderating Effect of Location on Small Firm Performance: Empirical Evidence. International Journal of Business and Management, 6(10), 178-192. https://doi.org/10.5539/ijbm.v6n10p178

Spring, A., \& McDade, B. (1998). Entrepreneurship in Africa: Traditional and contemporary paradigms. In B. E. McDade (Ed.), African entrepreneurship: Theory and reality, A Spring (pp. 1-36). Gainesville: University Press of Florida.

Sridhar, K. S., \& Wan, G. (2010). Firm location choice in cities: Evidence from China, India and Brazil. China Economic Review, 2l(1), 113-122. https://doi.org/10.1016/j.chieco.2009.11.003

The World Bank. (2013). Growing Africa: Unlocking the potential of agribusiness, The World Bank, Washington, $D C$. Retrieved from http://worldbank.org/INTAFRICA/Resources/africa-agribusiness-report- 2013

Thrikawala, S. (2011). Impact of strategic networks for the success of SMEs in Sri Lanka. World Journal of Social Sciences, 1(2), 108-119.

Tokman, V. E. (2001). Integrating the Informal Sector into the Modernization Process. SAIS Review, 21(1), 45-60.

Vwima, S. (2014). LE RÔLE DU COMMERCE FRONTALIER DES PRODUITS ALIMENTAIRES AVEC LE RWANDA DANS L'APPROVISIONNEMENT DES MÉNAGES DE LA VILLE DE BUKAVU (Province du Sud-Kivu). Retrieved from https://orbi.uliege.be/bitstream/2268/165882/1/th\%C3\%A8se\%20de\%20stany\%20pdf.pdf

Walker, E., \& Brown, A. (2004). What success factors are important to small business owners? International Small Business Journal, 22(6), 577-594. https://doi.org//10.1177/0266242604047411

Wang, Y. (2016). What are the biggest obstacles to growth of SMEs in developing countries? - An empirical evidence from an enterprise survey. Borsa Istanbul Review, 16(3), 167-176. https://doi.org//10.1016/j.bir.2016.06.001

Wangmo, C. (2015). Small medium enterprise (SME) bank financing constraints in developing countries: A case study of Buthan. International Journal of Arts \& Sciences, 8(5), 569-590.

Watson, J. (2007). Modeling the relationship between networking and firm performance. Journal of Business Venturing, 22(6), 852-874. https://doi.org/10.1016/j.jbusvent.2006.08.001

\section{Copyrights}

Copyright for this article is retained by the author(s), with first publication rights granted to the journal.

This is an open-access article distributed under the terms and conditions of the Creative Commons Attribution license (http://creativecommons.org/licenses/by/4.0/). 